\title{
On the ontology of fictional characters: A semiotic approach
}

\author{
Umberto Eco \\ The Department of Communication Disciplines, University of Bologna, \\ Via Azzogardino 23, 40122 Bologna, Italy \\ e-mail: umberto.eco@unibo.it
}

\begin{abstract}
Why are we deeply moved by the misfortune of Anna Karenina if we are fully aware that she is simply a fictional character who does not exist in our world? But what does it mean that fictional characters do not exist? The present article is concerned with the ontology of fictional characters. The author concludes that successful fictional characters become paramount examples of the 'real' human condition because they live in an incomplete world what we have cognitive access to but cannot influence in any way and where no deeds can be undone. Unlike all the other semiotic objects, which are culturally subject to revisions, and perhaps only similar to mathematical entities, the fictual characters will never change and will remain the actors of what they did once and forever
\end{abstract}

In 1860, on the verge of sailing through the Mediterranean to follow Garibaldi's expedition to Sicily, Alexandre Dumas stopped in Marseille and wanted to visit the Chateau d'If where his hero Edmond Dantès, before becoming the Count of Montecristo, spent fourteen years of his life, and was visited and rescued in his cell by the Abbot Faria. During his visit Dumas discovered that the visitors were shown the "real" cell of Montecristo, and the guides were speaking of him, Faria and other characters of the novel as if they had really existed. On the contrary, the same guides ignored the fact that a historical figure like Mirabeau had been imprisoned at the Chateau d'If.

Thus Dumas comments in his Memoirs: "It is the privilege of novelists to create characters who kill those of the historians. The reason 
is that historians only evoke mere ghosts, while novelists create persons in flesh and bones".

Once a friend of mine urged me to organize a symposium on the following subject: why - since we know that Anna Karenina is a fictional character who does not exist in our real world - do we weep for her deeds (or in any case, we are deeply moved by her misfortunes)?

Probably many sophisticated readers will not cry on the fate of Scarlett O'Hara but they, too, are certainly shocked by the fate of Anna Karenina.

I resolutely told my friend that this phenomenon had neither ontological nor logical relevance, and could only interest psychologists. Moreover, we certainly can identify ourselves with the cases of fictional characters, but this does not occur only in reading fiction. Many of us have sometimes thought of the possible death of a beloved person, and felt touched, if not moved to tears, even though they knew for sure that the imagined event had not taken place.

Later, I had to admit that there is a difference between weeping for the imagined death of our beloved and weeping for the death of Anna Karenina. In the first case, when after the daydream we are asked if our beloved has really passed away, we say that it was not true - as it happens when we suddenly awake from a nightmare and we realize with relief that it was only a hallucination. On the contrary, if we were asked if Anna Karenina died we would always answer positively, as if the fact that Anna committed suicide were true in every possible world.

Moreover, some people are pulled to suicide when abandoned by their beloved, but I have never heard of somebody who committed suicide because one of his friends had been abandoned by his fiancé. Thus it seems strange that, when reading that Goethe's Werther killed himself because of his ill-fated love, many romantic youngsters did the same, by the so-called Werther effect.

It seems funny that we deeply share the sorrow of somebody else only or mainly when we know that he or she never existed. But what does it mean that fictional characters do not have some kind of existence? According to Meinong, every representation or judgment 
has necessarily an object, even though this object is not necessarily an existing one. Centuries before Meinong, Avicenna said that existence was only an accidental property of an essence or substance (accidens adveniens quidditati). In this sense there can be abstract objects (like the number 17 of the right angle, which do not properly exist but subsist) and concrete objects like myself and Anna Karenina, with the difference that I am a Physically Existing Object while Anna is not.

Now, today I am not concerned with the ontology of fictional characters.

Since the core of my reflections today is why people feel moved by fictional characters, I am obliged to consider Anna Karenina as a mind dependent object, or the object of cognition. In other terms, my approach is not an ontological but a semiotic one. My concern is not in which sense the assertion Anna Karenina committed suicide is true but rather why a normal reader can accept the assertion Anna Karenina committed suicide as true even when he or she knows that Anna is a narrative figment?

By definition fictional texts clearly speak of non-existing persons and events and from the point of view of truth conditional semantics, a fictional assertion should always tell what is not real-life.

In spite of that we do not take fictional assertions as lies. First of all, in reading a piece of fiction we subscribe a silent agreement with its author, who pretends that something is true and asks us to pretend to take it seriously. Secondly, we know that every fiction designs a possible world and all our judgements of truth and falsehood must concern that possible world. In this way it is true in the Conan Doyle's world that Sherlock Holmes lived on Baker Street and false that he lived in Tartu and we can bet our life in this point.

\section{Fictional versus historical assertions}

Is a fictional assertion like Anna Karenina commits suicide by throwing herself in the path of a train as true as the historical assertion Adolf Hitler committed suicide (and his corpse was burned) in a bunker in 
Berlin? Our instinctive reaction would be that the assertion about Anna refers to an invention while the one about Hitler concerns what was really the case.

Thus, to be correct in terms of truth conditional semantics, we should say that it is true that Anna Karenina commits suicide by throwing herself in the path of a train is only another way for saying it is true in this world that in a Tolstoj's novel it is written that Anna Karenina commits suicide by throwing herself in the path of a train.

If so, in logical terms the truth about Anna would be true de dicto and not de re, and from a semiotic point of view it would concern the plane of expression and not the plane of content (or, in Saussure's terms, the level of the signifier and not that of the signified).

We can make true statements about fictional characters because what happens to them is recorded in a text, and a text is like a musical score. It is true that Anna Karenina commits suicide by throwing herself in the path of a train in the same way in which it is true that Beethoven's Fifth Symphony is in C minor (and not in F major like his Sixth) and begins with "G, G, G, E flat".

However, such a position is not completely satisfying from the point of view of the experience of a reader. By disregarding a lot of problems concerning the reading of a score as a complex process of interpretation, let us say that a musical score is a semiotic device which tells one how to produce a given sequence of sounds, and only after the transformation of a series of written signs into sounds the listeners can say that they are enjoying the Fifth Symphony (and this happens even to a very skilled musician, able to read the score silently, but in fact reproducing the sounds in his mind). When we say that it is true in this world that in a Tolstoj's novel it is written that Anna Karenina commits suicide by throwing herself in the path of a train we simply say that it is true in this world that on a given printed page there is a sequence of written words by pronouncing which (even though only mentally) the reader will afterwards realize that there should be a narrative world where persons like Anna and Vronskij exist. 
But when speaking of Anna Karenina or Vronskij, we usually do not consider any longer the page where we read about their vicissitudes but rather speak of them in the same way as if they were "persons".

Do not forget that our problem is why we can be emotionally moved by the deeds of fictional characters. In spite of every logician nobody is supposed to weep because Tolstoj wrote that Anna Karenina died. This is none of our business. One feels moved, at most, because Anna Karenina died - even if one ignores that it was Tolstoj who first wrote it.

Nobody can reasonably deny that Hitler and Anna Karenina are two different kinds of entity, with a different ontological status. Hitler existed physically and Anna did not. In spite of this we can say that not only fictional assertions but also the historical ones are de dicto: the students who write that Hitler died in a bunker in Berlin simply state that this is true according to their history textbook. In other words, except for judgments depending on my direct experience (of the kind it's raining), all the judgments I can make on the grounds of my cultural experience (that is, all those concerning the information recorded in an encyclopaedia) are based on textual information and, even though they seem to express de facto truths, they are merely de dicto.

Encyclopaedic assertions are, however, still open to revisions. If we keep a scientific mind, we must be ready to revise our opinions about Hitler's death whenever new documents will be discovered. Moreover, the fact that Hitler died in a bunker has already been questioned by some historians. On the contrary, the assertion Anna Karenina commits suicide cannot be cast in doubt.

\section{Fluctuating individuals in fluctuating scores}

Notice that what I have just said holds true for Anna Karenina, Hamlet and many others but not for every fictional character. There are a lot of interesting narrative characters who have remained 
unknown to the great majority of readers and stand so to speak prisoner of their original score. On the other hand, I have recently read that according to a reliable test, many Britons believe that Sherlock Holmes and Eleanor Rigby really existed.

Hamlet or Sherlock Holmes acquired a sort of existence independent of their original scores. Many fictional characters "live" outside the score which has given them existence, and move to a zone of the universe which we find very difficult to delimit. Some of them even migrate from text to text because the collective imagination has, over the course of the centuries, made emotional investments in them and has transformed them into fluctuating individuals.

It is not indispensable that they come from great works of art or from popular legends. In this sense we have appointed Hamlet and Robin Hood, Heathcliff and Milady, Leopold Bloom and Mickey Mouse as fluctuating entities. Becoming a fluctuating entity does not depend on the aesthetic qualities of the original score. Why so many people suffer for the suicide of Anna Karenina and only a small bunch of Hugo's addicts sympathize with the suicide of Cimourdain in Ninety Three? Personally I feel the fate of Cimourdain (a gigantic hero) more touching than the one of that poor lady. Too bad, the majority is against me.

On the contrary, Dido or Medea, Don Quijote, Madame Bovary, Holden Caulfield, Gatsby, Philip Marlowe, Maigret or Hercule Poirot became individuals living outside their original scores, and even those who have never read these original texts can claim to make true statements about them.

Being independent of the text and of the possible world where they were born, they are (so to speak) circulating among us, and we encounter some difficulties in not considering them real persons.

Let us define the epistemological status of these entities better.

A fluctuating character exhibits a core of properties that seem to be identified by everybody: for instance Little Red Riding Hood is a girl, she wears a red cap, she met a wolf who later devoured her and her grandmother, even though different people can have different ideas 
about the age of the girl, the kind of food she had in her basket, and so on.

It has been suggested that a fictional character is an object of higher order, that is, one of these objects that are something more than the sum of their properties. What is crucial for the recognition of the object is that it maintains a Gestalt, a constant relation between its elements even if these elements are no longer the same. A typical example of higher order object is a melody. Chopin's Piano Sonata No.2 in B flat minor op. 35 will remain melodically recognizable even if played with a mandolin. From an aesthetic point of view the result would be disastrous, but the melodic pattern would be preserved and it would be recognizable also if some notes would be dropped.

It would be interesting to decide which notes can be dropped without destroying the musical Gestalt and which ones are on the contrary essential or diagnostic in order to identify that melody as such. It is not a theoretical problem, it is rather a task for a musical critic, and it will have different solutions according to the object of analysis. However, this reflection is important because the same problem exists when we are dealing with a fictional character. There are two versions of Little Red Riding Hood's story, the Perrault's and the Grimms' one, and in the former the girl is not rescued by the hunters and dies devoured by the wolf. Curiously enough, she remains the same individual in both versions, while (I suspect) nobody would recognize her if she appeared as a young lady, dressed like a princess, without the red cap.

Would Madame Bovary still be Madame Bovary if she did not commit suicide? There is a short story by Woody Allen called The Kugelmass Episode (published in Side Effects) where Madame Bovary is brought by a sort of time-machine to have a love affair in today's New York. Emma Bovary appears as a parody of the original character, she wears contemporary dresses and behaves as a Tiffany-goer, but she is still recognizable because she keeps most of her basic properties namely, she is a petty bourgeois and the wife of a doctor, she lives usually at Yonville, she is unsatisfied with her countryside life, she is inclined to adultery. In Allen's story the suicide is not mentioned; but 
it is essential for the ironic quality of the narration that Emma be fascinating (and desirable) just because she was on the verge of committing suicide - and Kugelmass is obliged to science-fictionally enter Flaubert's world before Emma had her last adulterous relation, just in order not arrive too late.

We can thus assume that a fictional character remains the same even if it is set in a different context, provided diagnostic properties (to be defined for each case) are preserved.

\section{Fictional characters as semiotic objects}

At this point, I cannot escape the basic ontological question: which kind of entities are fictional characters and in which way they, if do not exist, at least subsist?

Being a set of properties, a fictional character is a semiotic object. I define so every device by which an expression conveys a set of properties as its content - provided one assumes that every expression (a word, an image or some other device) is, as Searle has suggested, a peg for hanging descriptions, or properties.

From my point of view, these "pegs" are not only proper names but all expressions which convey as their proper content whatever we are used to call the meaning or the signified of the expression: the idea of an animal, of a place, of a thing, of a feeling, of an action, of a natural law like universal gravitation, of a mathematical entity, et cetera. Thus the expression dog conveys as its content the properties of being an animal, a mammal, a canid, a barking creature, the man's best friend and many others registered by a comprehensive encyclopaedia. These properties can at their turn be interpreted by other expressions and the series of these interrelated interpretations constitutes the whole of the notions shared by a community, socially and collectively recorded.

There are many kinds of semiotic object, some of them representing Physically Existing Objects or classes of Physically Existing Objects (like the ones conveyed by such terms as horse or flower, and 
more or less corresponding to the classical universals like the Platonic "horseness"), others representing abstract notions or ideal objects (like freedom and justice or square roots), others that have been labelled as social objects, among which belong marriages, money, diplomas, and in general all entities whose nature is a law established by a collective agreement. But there are also semiotic objects representing human (or humanized) individuals. I do not share the theory of Kripke's rigid designation and I believe that the proper name 'Napoleon' conveys the properties of being born in Ajaccio, to have been a French general, to have become an emperor, to have won at Austerlitz, to have died at Saint Helena on May 5, 1821, and so on. The same holds for the proper name 'Barack Obama'. Among the bearers of proper names, the great majority has the property of having existed physically in some spatio-temporal location. Notwithstanding there are proper names conveying the properties of individuals characterized by the feature of being fictive (and as such they are usually registered by a good encyclopaedia).

The existence of fictional characters obliges semiotics to revise some of its approaches that risk looking excessively simplified. The classical semantic triangle usually appears this way (Fig. 1):

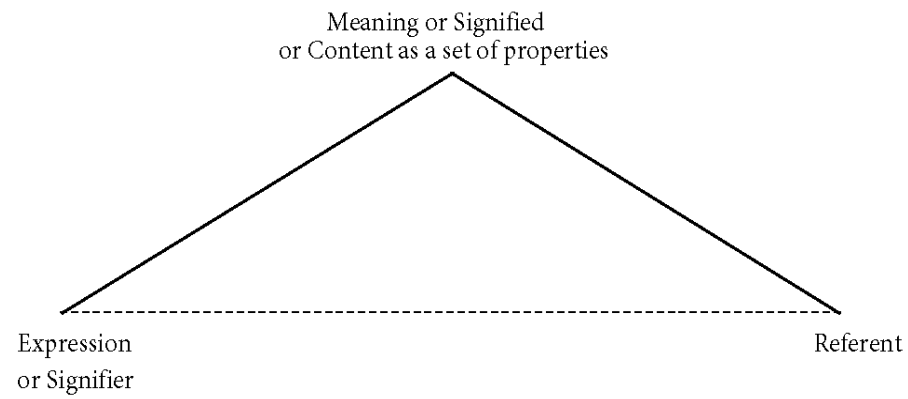

Figure 1. The classical representation of the semantic triangle. 
An expression along with its content is a semiotic object. The referent is inserted in this triangle owing to the fact that we frequently use expressions in order to indicate something physically existing in our world. This happens when we speak of my friend John, of Milan or of Tartu, of that microphone on that table, of the fact that outside it's raining.

I do not believe that we are performing an act of reference when we say that dogs are animals or that all cats are nice: in these cases we are still making judgements about a given semiotic object (a class) predicating some of its properties. In other terms, a scientist can claim to have discovered a new property of apples, and in asserting that she is still pronouncing a semiotic judgement; whereas she implements an act of reference only when she says or writes in her protocols that she tested those properties of apples (in general) on the real individual apples A, B, C (then indicating the series of real objects she used to perform her experiments to legitimate her induction).

We perform acts of reference when we speak of individuals but there is a difference between referring to existing individuals and mentioning individuals who existed in the past. In the content of the expression 'Napoleon' the property of being dead on May 5, 1821, should be registered among his properties. On the contrary, the properties of the content of the expression 'Obama', must include being alive and the president of the U.S.

When referring to still living individuals the semantic triangle could be the following (Fig. 2):

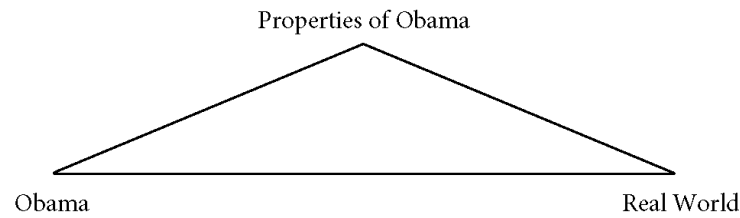

Figure 2. The semantic triangle when referring to a living individual called Obama. 
In this case speakers who utter $p$ referring to Obama, invite their addressees to verify $p$ (if they want) in a precise spatio-temporal location of the physically existing world. On the contrary, who utters $p$ referring to Napoleon is not inviting people to verify $p$ in a past world. Unless one has a time-machine, one cannot go back in the past to check if Napoleon really won at Austerlitz. Any assertion about Napoleon either says which are the properties conveyed by the expression 'Napoleon', or concerns and refers to a newly found document that changes what we believed until now, let's say, about the death of Napoleon - for instance, that he did not die on May 5th but on May 6th. Only when the scientific community has verified that the document under question is a Physically Existing Object, we can proceed to the correction of the encyclopaedia, that is, of the properties attributed to Napoleon as a semiotic object.

It can happen that Napoleon becomes the main character of a biographical reconstruction (not to speak of a historical novel) that tries to make him live again in his time, reconstructing his actions and even his feelings. In this case, Napoleon becomes very similar to a fictional character. We know that he really existed but in order to take part in his life we try to imagine his past world as it were a possible world of a novel.

What really happens with fictional characters? It is true that some of them are introduced as somebody who lived once upon a time (like Little Red Riding Hood and Anna Karenina), but we have ascertained that by virtue of a narrative agreement the reader is bound to take for true what is narrated and to pretend to live in the possible world of the narration as it were his or her real one. At this point it is irrelevant whether the story speaks about an allegedly living person (like a given detective acting in Los Angeles) or about an allegedly dead person. It is like in this world somebody told us that one of our relatives has just dead. Our emotional involvement would be about somebody who is still present in the world of our experience.

Thus the possible semantic triangle should assume this new form (Fig. 3). 


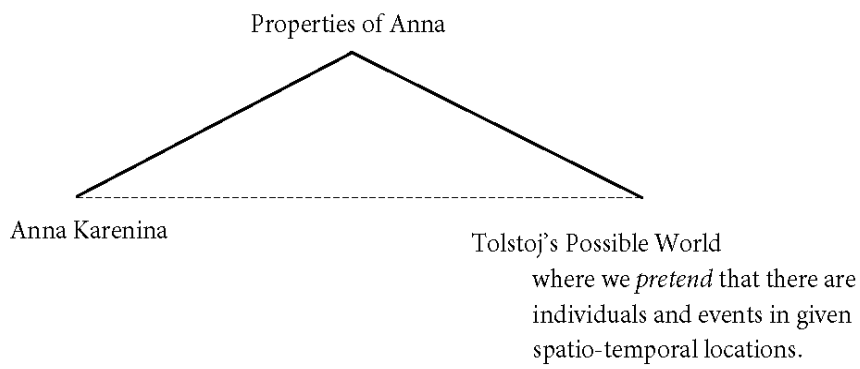

Figure 3. Semantic triangle in case of fictional characters.

When speaking of Anna Karenina, one makes a virtual reference to the inhabitants of a possible fictional world as if they were real persons. When we are shocked by a daydream where our beloved dies, at the end of our reverie we come back to our everyday life and we recognize that we had no real reasons to worry.

To be permanently sentimentally involved with the inhabitants of a fictional possible world we must then satisfy two requirements: (i) we must live in the fictional possible world as in an uninterrupted daydream; and (ii) we must in some way behave as if we were one of its characters.

It can thus happen that, when we enter a very absorbing and captivating possible narrative world, a textual strategy can provoke something similar to a mystic raptus or to a hallucination, and we simply forget that we entered an only possible world. It happens especially when we meet a character in its original score or in a new enticing context. But since these characters are fluctuating and, so to speak, they come and go in our mind, like the women in the James Prufrock's world, talking of Michelangelo, they are always ready to mesmerize us, and to make us believe that they are among us.

As for the second requirement, once we live in a possible world as if it was the real one, we can be disturbed by the fact that in that world we are not, so to speak, formally registered (in that world we do not exist) and we are drawn to assume the personality of somebody else 
who has the right to live there. Thus we identify ourselves with one of the fictional characters.

However, when awaking from a daydream in which our beloved dies, we recognize that what we imagined was false and we take for true the assertion my beloved is still well and alive. On the contrary, when the fictional hallucination stops (simply because le vent se lève, il faut tenter de vivre), we continue to take for true that Anna Karenina committed suicide, Oedipus killed his father and Sherlock Holmes lives on Baker Street.

It happens that, being fluctuating entities, these faithful companions of our life have an additional virtue: unlike all the other semiotic objects, which are culturally subject to revisions, and perhaps only similar to mathematical entities, they will never change and will remain the actors of what they did once and forever - and it is because of the incorrigibility of their deeds that we can dare to say that it is true that they were or did this and that.

\section{On other semiotic objects}

Is there anybody else who shares the same fate? Yes, there are the heroes and divinities of every mythology and many other legendary beings like unicorns, dwarves, fairies and Santa Claus, as well as 99\% of the entities in various religions. It is obvious that for an atheist every religious entity is a fictional one, while for a believer there is somewhere a spiritual world of supernatural objects (like gods, angels and so on), inaccessible to our senses but absolutely "real" (and in this sense an atheist and a believer rely on two different ontologies). However, if Roman Catholics recognize a personal God as really existent and assume that from Him and from His Son proceeds the Holy Ghost, then they must consider Allah, Shiva or the Great Spirit of the Prairies as mere fictions - designed by a sacred narration. Likewise, for a Buddhist the God of the Bible is a mere fictional individual and Gitchi Manitou is an equally fictional individual for a 
Muslim as well as for a Christian. This means that for a believer in whatever confession all the religious entities of the other religions (that is, an overwhelming majority of entities) are fictional individuals - so that we are entitled to consider more or less ninety per cent of religious entities as fiction.

One could object that, at least for the believers in religion $\mathrm{X}$, their divinity really exists, while for all the fans of Alice she is a nonPhysically Existing Object. But if we were going to test the true beliefs of common people we would discover that many Christians are not sure that Jesus really resurrected; others go to the Mass but are very doubtful about the real existence of the Holy Ghost; others sincerely believe in God but think that Jesus was only a very virtuous human being; and finally many Catholics still consider certain saints as persons who really existed while the Roman Church has officially declared that they were a legend. Conversely, we have seen that some Britons believe that Holmes was a real person and many Christian poets started their works by invoking the Muses or Apollo - and we do not exactly understand if they simply used a literary topos or were in some way taking the divinities of the Olympus seriously. Many mythological characters have become protagonists of narrations, and in a symmetrical way many protagonists of secular narrations have become very similar to the characters of mythological tales, so that mythical heroes and gods, literary characters and religious entities are frequently separated by imprecise borderlines.

\section{The ethical power of fictional characters}

We have said that unlike all the other semiotic objects, which are culturally subject to revisions, and perhaps only similar to mathematical entities, fictional characters will never change and will remain the actors of what they did once and forever - and it is because of the incorrigibility of their deeds that we can dare to say that it is true that they were or did this and that. 
That is why they are important for us, even from a moral point of view.

Just think - we are watching Oedipus Rex and we feel sorry that this fellow did not take any other road instead of the one where he met and murdered his father, and wonder why he reached Tebes and not, let us say, Athens, where he could have married Phryne or Aspasia? We read Hamlet asking why such a nice boy could not marry Ophelia and live with her happily, having killed that scoundrel of his uncle and gently kicked his mother out of Danmark? Why Heathcliff did not tolerate his humiliations a little more, waiting until he could marry Catherine and live with her as a respected country gentleman? Why prince Andrej could not recover from his mortal illness and marry Natasha? Why Raskolnikov had the morbid idea of killing an old lady instead of finishing his studies and becoming a respected professional? Why, when Gregor Samsa was transformed into a horrible bug, a beautiful princess did not arrive, kissing him and transforming him into the most handsome young man in Prague? Why on the arid hills of Spain Robert Jordan could not beat those fascist pigs and join again his sweet Maria?

Now, in principle it is enough to buy a computer program for rewriting Oedipus, Hamlet, Wuthering Heights, War and Peace, Crime and Punishment, The Metamorphosis, For Whom the Bell Tolls. We can do it. But do we really want to do so?

The devastating experience of discovering that, in spite of our wishes, Hamlet, Robert Jordan or Prince Andrej died, that things happened in that way, and forever, no matter what we wanted, hoped or yearned during the course of our reading, makes us to feel the shiver of Destiny. We realize that we cannot decide whether Ahab will capture the Whale or not. The real lesson of Moby Dick is that the whale goes wherever She wants.

The charm of the great tragedies comes from the fact that their heroes, instead of escaping an atrocious fate, fall into the abyss that they have dug with their own hands because they do not know what expects them - and we, who we see clearly where they are blindly going, cannot stop them. We have a cognitive access to the world of 
Oedipus and we know everything about him and Jocasta but they, even if living in a parasitical world which depends on our own, do not know anything about us. A fictional character cannot communicate with his/her counterparts in the actual world. ${ }^{1}$

Such a problem is not as whimsical as it seems. Please try to take it seriously. Oedipus cannot conceive of the world of Sophocles otherwise he would have not married his mother. Fictional characters live in an incomplete (or, to be more rude and politically incorrect) handicapped world.

But when we really understand their fate, we start to suspect that we, too, as the citizens of the actual world, frequently undergo our destiny just because we think of our world in the same way as the fictional characters think of their own. Fiction suggests that perhaps our view of the actual world is as much imperfect as that of fictional characters. This is why successful fictional characters become paramount examples of the 'real' human condition. ${ }^{2}$

\section{Об онтологии литературных героев: семиотический подход}

Почему нас глубоко затрагивает судьба Анны Карениной, если мы полностью осознаем, что она - вымысел и в реальном мире ее не существует? Но в каком смысле литературные герои не существуют? Темой настоящей статьи является как раз онтология литературных героев. Автор приходит к выводу, что «удавшиеся» литературные герои становятся важными примерами «настоящей» жизни, так как они живут в неполноценном мире, который для нас познавательно доступен, но на который мы не можем повлиять и в котором случившееся уже нельзя изменить. В отличие от всех других семиотических объектов, которые изменяются в культуре (и подобно, возможно, только математическим объектам), литературные герои никода не меняются и остаются героями своих действий во веки веков.

\footnotetext{
1 On these questions see Eco, Umberto 1979. The Role of the Reader. Bloomington: Indiana University Press.

2 A version of this text has been presented by the author in the University of Tartu on May 6, 2009.
} 
Kirjanduslike kangelaste ontoloogiast: semiootiline lähenemine

Miks meid liigutab sügavalt Anna Karenina saatus, kui me oleme samal ajal täiesti teadlikud sellest, et Anna Karenina on lihtsalt kirjanduslik kuju ja teda ei ole reaalselt meie maailmas olemas? - Kuid mida see tähendab, et kirjanduslikke kangelasi pole olemas? Käesoleva artikli teemaks on kirjandustegelaste ontoloogia. Autor järeldab, et edukatest kirjandustegelastest saavad "tegeliku" elu väljapaistvad näited, sest nad elavad ebatäielikus maailmas, millele meil on kognitiivne ligipääs, kuid mida me ei saa mõjutada ning kus tegusid ei saa olematuks teha. Erinevalt kõigist teistest semiootilistest objektidest, mida kultuuriliselt muudetakse, ja sarnaselt ehk ainsana matemaatilistele objektidele, ei muutu kirjanduslikud kangelased kunagi ning jäävad oma tegude kangelasteks igavesest ajast igavesti. 